\title{
3 \\ Economic Changes and the Unequal Lives of Young People among the Wampar in Papua New Guinea
}

\author{
Doris Bacalzo
}

\section{Introduction}

The first time that I conducted fieldwork in a Wampar ${ }^{1}$ village in Papua New Guinea (PNG) in 2009, I talked a lot with young interethnic people who spoke about their contested belonging. These were children with a father who was culturally categorised as an ethnic 'other' relative to the Wampar, and they were accordingly excluded from inheriting and accessing land of the lineage of their Wampar mother. To be born only with a Wampar mother was no longer a guarantee of incorporation into a Wampar lineage group, which is a reversal of practices in the previous generations. The older generation of the parents explained that economic conditions have changed, which prompted them to make this critical social differentiation. Seven years later, upon my return to the same village in 2016, I observed newer forms of inclusion that, to an extent, are a

1 I use the term Wampar here as the locals do when they identify and differentiate themselves from other ethnic groups in PNG. In this chapter, unless otherwise specified, I refer to the Wampar in my field site and not necessarily the whole of the Wampar-speaking and self-identifying population in Morobe province that are mostly linked by kinship and that share similarities, but also show differences that cannot be solely reduced to the particularities of their ecological and geographic circumstances. 
reversal of the earlier exclusionary politics. An investigation into what happened within just a decade that so affected the lives of young people of interethnic descent among the Wampar is the focus of this chapter. I situate their experiences and the implications for their future in the current context of local engagements with competing large-scale capitalist projects.

Young people's participation in the household and local economy form aspects of their development that are thus bound to particular social relations and cultural context (Lancy 2018). Among the Wampar, kin relations are central to the organisation of social life (Beer 2006a) and to the experiences of the young: the way in which a person is categorised socially and relationally bespeaks certain political possibilities and determines the rights to inherit and access land. Claims of ownership to property such as land, and the rights and entitlements over it, are thus about social relations between people (Hann 1998). Among the Wampar, to belong to a mpan - the social unit defining how land is held, which is normatively, and increasingly in practice, reckoned via patrilineal descent-entails being able to exercise and enjoy crucial socioeconomic rights to the fruits of collectively and customarily held land. Young people of interethnic descent with non-Wampar fathers thus have to negotiate kin relations and other social circumstances to be able to use land as a productive resource. The experience of growing up and the constraints and possibilities for young people's future are, however, also very much inflected by rapidly changing economic conditions, as these have effects on the social relationships, including those connected to land and its use. Claims and forms of ownership over land are changing, with direct consequences to all involved, especially to those with only a tenuous claim to this form of property.

The transitions in economic life among the Wampar are progressing with increasing rapidity. Within a few years, people went from subsistence production and a more locally and directly controlled production of cash crops for the domestic market to an increasingly internationally and globally controlled capitalist economy with the entry of large-scale, internationally financed industries in the form of mining, biomass energy ${ }^{2}$ and palm oil production. When land, as property, and its ownership has to be institutionalised in ways defined by the state, as a prerequisite

2 Biomass energy is a renewable form of energy that is sourced from organic materials, which in my field site is being developed out of wood from eucalyptus trees to generate electricity. 
for engaging with these new large-scale projects, the relationships relating to land tend to change also, undergoing a revaluation that implicates membership in landowning units (Minnegal et al. 2015). These reconfigurations of economic life thus also directly implicate kin relations through the emergence of new corporate forms of ownership, leadership and the means for control over land. While lineage leaders keenly take the lead in the process of reordering relationships and in engaging with the new global capitalist projects, the young people in the background are at times more critical of the changes, as they are directly affected by the decisions that their elders made.

Focusing on young people allows me to highlight the consequences that these realignments have on the less powerful and to establish some conjectures about possibilities for the future. Young people of interethnic descent are in a particularly tenuous position-for within just a decade, they have been exposed to marked changes to the political legitimacy of their claims to membership in lineage groups, from inclusion to exclusion and then again inclusion, implicating their access to land and the benefits emanating from it. The embeddedness of young people in particular political and economic contexts thus shapes their life trajectories, with some in a better position than others. Their experience is further differentiated by the circumstances of the family and lineage of which they are a part.

In this chapter, I situate the possibilities and limits of full participation in economic life for young people of interethnic descent among the Wampar in relation to the organisation of social relationships as affected by changing economic conditions. I maintain that outcomes cannot be delinked from historical processes of social transformation, both locally and globally, because the effects of changing economic conditions and the process of encompassment (LiPuma 2001) have repercussions on the organisation of property relations. I further explore the emerging social conditions with the introduction of new forms of representational and legal collectivities in the process of corporatisation that is quickly transforming the organisation of membership and decision-making processes. Drawing on my ethnographic study among the Wampar in the Markham Valley, specifically in the village of Dzifasing, I first introduce pertinent sociocultural categories of differentiation in the life cycle among the Wampar before describing the rapidly changing economy in the field site and the repercussions that this has on young people of interethnic descent. 


\section{Growing Up in Dzifasing}

Dzifasing is one of the eight Wampar villages situated on the vast plains of the Markham Valley. ${ }^{3}$ It is about $60 \mathrm{~km}$ from the centre of Lae, the second largest city in PNG, which is a major hub of trade with an important seaport and airport and an expanding urban topography. In this setting, the village of Dzifasing can be classified as peri-urban. The Highlands Highway cuts through the centre of the village and is lined with shops, a gasoline station, two major marketplaces, a primary school, a small health centre (still referred to as an Aid Post) and a police station. The village has long attracted migrants from all over PNG, with migration increasing significantly since the upgrading of the highway in the 1970s. Aside from migrant workers, who eke out a living in precarious patronage relationships with some Wampar families, there are a high number of in-married male and female migrants who have settled down permanently in Dzifasing and who have established interethnic households and families. It is in this context of interethnic marriages that new social categories of identities for the offspring of such marriages emerged. ${ }^{4}$

Growing up in Dzifasing means going through life stages that are culturally marked. The Wampar term for a man is ngaeng and aff for a woman. In the social life cycle, to be a ngaeng means to be cut out for assuming responsibilities, ready for marriage and having the skills and capacities for starting his own household. The female counterpart afi knows about cultivating and tending a garden for subsistence and maintaining the reproductive needs of her new household and the lineage that she has married into. ${ }^{6}$

Children are differentiated in Wampar terms based on relative age: the small and young child is called garafu naron, regardless of gender. When they reach puberty, terms become differentiated according to gender. Young women are referred to as daer and young men as bangets.

3 The other villages are Tararan, Gabsongkeg, Ngasawapum, Munun, Gabantsidz, Wamped and Mare.

4 For analysis of marriage patterns and changing demography in different Wampar villages see Beer (2006a), Beer and Schroedter (2014), Fischer (1975), Schulze et al. (1997) and Kramp (1999). 5 To make a distinction on the Wampar and Tok Pisin languages in this text, the former in addition to being italicised is underlined. In a multilingual environment, the mixing of language is very common. There are over 800 ethnolinguistic groups in Papua New Guinea.

6 While a woman's marriage to a man signals a transition towards her incorporation into the man's lineage, it does not mean cutting off her social ties, rights and obligations to her natal lineage. 
At this stage, young men begin to build their own temporary house, the tao $\underline{n t s a}$ (bachelor's house) - or hausboi in Tok Pisin, the Melanesian Pidgin. A child or a young man is not yet socially accorded the term ngaeng, except for gender identification, as ngaeng also means male. ${ }^{7}$ A socially mature man (ngaeng) and woman (afi) are capable, skilled and enculturated reproductive individuals with a sense of individual and collective identity and the comportment and rights that are implicated in their social relationships. Beside the Wampar terms, the Tok Pisin term yangpela manmeri (young people) or yut (youth) are also widely used. ${ }^{8}$ In any case, it is the social meaning behind what it means to be culturally a ngaeng or afi and not the physiological age alone that counts. ${ }^{9}$

A ngaeng Wampar is a person who is ethnonymically identified as one of their own-for to be of a different ethnicity, a non-Wampar, is to be called yaner, a foreign person relative to the Wampar. ${ }^{10} \mathrm{~A}$ child born with a nonWampar father is referred to as ngaeng yaner naron, where the last term in this instance stands for 'child' or 'offspring'. Children with Wampar fathers are then called ngaeng Wampar naron. It is common to hear the terms in a mix of Pidgin and Wampar-pikinini bilong ngaeng Wampar (child or children of a Wampar father) and pikinini bilong ngaeng yaner (child or children of a non-Wampar father).

The Wampar differentiate and identify relationships by referring to one's $\underline{m p a n}$ and sagaseg. The mpan refers to the collectivity of all the descendants of a named ancestor (from which the mpan takes its name) and thus can be regarded as an extended family or lineage. The term sagaseg refers to more encompassing named groupings, akin to the concept of a 'clan', which among the Wampar remains an instrumental concept in the process of adapting in the changing social, economic and political situations. Men

7 While the term ngaeng is a social marker for gender and life stages differentiation, it also simply means a 'person'.

8 The local usage of the term $y u t$ is rather fluid and its meaning is not bound by the age-based definition that is used by the PNG government, which ranges between 12 and 25 years old (Noble et al. 2011). It is also not unusual that unmarried and married women and men in their 30 s continue to lead and participate in local youth programs.

9 Older parent generations, as those in their 50 s and 60 s, criticise how younger generations today are marrying too young, to mean that they are not yet culturally fit to start their own households. It does not seem unusual to find some married couples, even in their late 20 s, who eat with and remain part of their parents' household, usually the husband's, for more than a year.

10 This term is mostly used for other New Guineans (Beer 2006b). The Melanesian Pidgin term, 'white man' is still widely used for foreign nationals who can be further specified based on their known country or international region of origin, such as 'Kongkong' for all those perceived to be from China. The nomenclatures are elaborated through contexts of contact and interactions - and thus keep evolving. 
who are lineage leaders and who are at the forefront of such engagements are referred to as ngaeng faring, which is the Wampar rendering of the commonly used Tok Pisin term, big man. ${ }^{11}$ The first-born son usually gains this status, but it is not necessarily exclusive to him, as other brothers can have the same recognition through their active role as spokespersons for their lineage. ${ }^{12}$ The term faring is also socially associated with someone, male or female, who would already have grandchildren, the descendants of whom are vital in the social reproduction of the lineage. While women would also be referred to as aff faring in this same vein, they are normatively not the lineage leaders in the context of representation, especially with outside groups and with their engagement with the state and companies. However, there are outspoken and respected women who are equally heard during family and lineage meetings. There is a case of a lineage that has no sons in which the daughters stand up for their lineage. Locals recognise these daughters as the proper lineage representatives during community meetings, even if their participation in male-dominated fora is limited. ${ }^{13}$

In the next sections, I describe the experience of young people with a non-Wampar father and explore how recent developments and the transition from a subsistence and small cash crop economy to the entry of large-scale and international capitalist projects are effecting changes on the young people's social position and forms of incorporation and economic participation.

11 For an understanding of the Melanesian 'big man' concept, see Roscoe (2000, 2012). See also Godelier and Strathern (1991) for a clarification and elaboration of the 'big men' and 'great men' contrast in different social contexts in Melanesia. In the precolonial period, Wampar male warriors who gained prestige in their leadership during warfare are referred to as gar $\underline{\text { a weran }}$.

12 The distribution of the role, as a spokesperson, is not unusual and again manifests in the current context of engagement with large-scale capitalist projects, when other brothers share the duties and responsibilities of representation and negotiations. When this happens, it is usually a mutually recognised and agreed process between the brothers.

13 On the reconfiguration of gender relations and emerging inequalities among the Wampar in the postcolonial and recent context of large-scale capitalist projects, see Beer (2018). 


\section{Economic Changes and the Effects on Social Relationships}

In 2009, a local government official from Dzifasing spoke of the Markham Valley as the 'fruit bowl' of PNG. ${ }^{14}$ The valley has considerable areas of fertile soil. Locals already sell a range of mostly indigenous varieties of cooking and sweet bananas, papaya, mango, pineapple and coconuts in their self-managed marketplaces along the highway or at the city market in Lae. Women collect these products from their gardens, where they plant several crops. These gardens are usually established on the land either of their natal or their spouse's lineages and are typically in or near secondary forests, hidden from sight if one only drives along the highway through a grassland savannah.

Before 2007, the Markham Valley had been one of the main production areas for betel nut (buai), a mild stimulant and an essential commodity in PNG. ${ }^{15}$ Betel nut palms were planted either as pure betel palm orchards, usually on land belonging to one's lineage, or were then interspersed in subsistence gardens. Subsistence gardens were established in grassland or secondary forest, often not too far from one's house, even if the forest or grassland did not belong to one's lineage. Since betel nut palms have a longer productive lifespan than vegetables and some bananas, ${ }^{16}$ the garden plot then over time is transformed into a betel nut palm orchard. People said that everybody had enough land to use for planting betel nut palms. Usufruct rights were accorded to anyone who expended labour in clearing a garden in the grassland. This right could then be transferred down the generations, and descendants of ngaeng yaner fathers could thus continue to use old garden sites of their fathers. While there is a difference regarding the size and location of landholdings between lineages, planting betel nut palms did not require a vast area, as they could be planted in one's backyard or in vegetable and banana garden plots.

14 The whole of the Markham Valley, touted for its fertile plains, is increasingly known in the national and international scene of business, development and media world as the 'food bowl' of PNG. See, for example, the recent report of the Oxford Business Group (2016).

15 See Sharp (2016) for a description of the betel nut trade in PNG.

16 While most bananas need to be replanted from suckers to remain productive, the Wampar also have some varieties of bananas called oriats and mayamas that produce fruit for about 15-20 years from the same underground stem. 
Wampar thus had a quick and straightforward way of generating a relatively significant cash income, by selling the harvested nuts to bulk buyers mostly from the Highlands. Some men were also more actively involved in the betel nut trade as middlemen between Watut and Wampar producers and Highland buyers. Women and men alike would travel to other towns, even to the capital Port Moresby, to sell their betel nut there. People reminisce about the 1990s and the early 2000s as their taim bilong buai, the time when the betel nut economy was flourishing, and they always had enough cash at hand by their local standards. It was also the time that approximates what I qualify as a more 'egalitarian' local economy and inclusive social relations. Young and old people attest to how women and men, girls and boys, ngaeng Wampar as well as the ngaeng yaner among them, all could participate in the production and marketing of betel nut. Accordingly, the difference in how much money one generated at that time did not lie in how much land one's own family or lineage claimed, but on how much land one was able to access to plant as many betel nut palms as possible. Industriousness is a trait that locals also link to through the act of accessing available land and planting betel nut palms.

Hardworking and industrious men and women are referred to as ngaeng a gom and afi gom, respectively. ${ }^{17}$ To be so is a desirable trait and, together with the virtue of generosity, this makes up a ngaeng or af ngarubingin, a good person. A selfish person, in contrast, is called a ngaeng a mut-eran (literally, a person who stinks). Anyone, regardless of descent, is measured in the same terms. A non-Wampar father and his children are thus not different when it comes to the acquisition of such traits. During the time of the betel nut economy, they were neither constrained from accessing land for subsistence nor were they prevented from participating in the production and marketing of betel nut.

In 2007, an unknown pest completely devastated the betel nut orchards, rendering the palms unable to produce flowers and nuts- the trunks became brittle and often the top crown was blown off by wind, killing the palm outright. This catastrophe forced a rapid economic transition. Families had to turn back to their other garden crops to sell in local markets, while those who had available and accessible land focused on

$17 \underline{\text { Gom }}$ is a Wampar term commonly heard to refer to productive work and to a subsistence garden, which traditionally and still today is an important site for their sustenance and source of food contribution for exchange rituals and contemporary feasts in church, school and political events. See Lütkes (1999) for notions of work and economic life in Tararan, another Wampar village. 
planting cacao trees and expanding their cattle herds. In contrast to betel nut production, both cacao and especially cattle require much larger tracts of land..$^{18}$ Lineage leaders began to fence land that they claimed for their lineage and, with that, disputes about boundaries and rightful ownership increased. Along with new disputes, old and dormant land cases were resurrected, reaching the attention of land mediators and the village courts.

The shift to cacao plantations and the intensification of cattle herding also linked the local economic life to the vagaries of the global market. Betel nut, being an only locally traded commodity, had its price swings, but these were seasonal and correlated to locally easily recognisable differences in supply. With cacao, if there is a bad harvest, the price on the global market could still be exceptionally low. The competitive international market similarly affects cattle farming for beef consumption and live export. Cacao plantations and cattle ranches also require a much larger work input, placing higher demands upon female and younger male labour. Gender relations are also affected, as women formerly had a dominant position in the sale of betel nuts, whereas the sale of cattle or cacao is mainly in the hands of men.

This economic downturn and the higher pressure on available land led to a preoccupation in social differentiation on who has rights to access land and who does not, and who can stay and reside on Wampar territory and who will have to leave. It was a differentiation drawn along the lines of ethnicity, descent and gender that directly affected children of ngaeng yaner (Bacalzo 2012). At the end of the betel nut economy, community meetings were held to discuss 'rules' to secure land for the Wampar and even to banish ngaeng yaner and their families from their proclaimed Wampar territory. However, the rules did not become an official law at the level of the local government. ${ }^{19}$ The decision was left to the lineage leaders to discern for themselves regarding how they would apply the rules. Arguments for the exclusion of the ngaeng yaner living among them not only as settlers, but also those who were in-married men, and their sons and daughters-as pikinini bilong ngaeng yaner - were frequently heard. The rule, which in the words of a local government official served as a 'guide', was applied

18 See Bacalzo (2012) for the effects of the shift to cacao and the intensification of cattle herding on local social relations.

19 Papua New Guinea has three levels of government: national government, provincial government and local-level government. 
variably and to different degrees. However, outright forms of exclusion existed, as in the case of a court battle between a Wampar lineage leader and a male descendant of a ngaeng yaner with a Wampar mother. The former wanted to prevent the latter from continuously using a piece of land that forms part of a larger area that he wanted to convert into a cattle range. The latter defended his customary right to continue the use of that piece of land that his parents had previously cleared for gardens. It is on this land that he had planted cacao that was interspersed in their subsistence garden.

\section{Large-Scale Projects and Reorganising Collectivities}

With the arrival of large-scale capitalist projects in the last few years, the formalisation of land ownership became urgent and the process of corporatising landowning units accelerated. Many different new corporate and business entities have since then been established in Dzifasing. The first project that drew local attention is a gold and copper mining project at Wafi-Golpu, which in 2009 was already inching towards feasibility. An application for a mining licence was eventually lodged in 2016. The proposed Wafi-Golpu mine is a joint venture between an Australian mining company, Newcrest, and a South African one, Harmony Goldand together they plan to establish a world-class underground copper and gold mine that is about $30 \mathrm{~km}$ south of Dzifasing, upstream along the Watut River. There had been ongoing exploratory drilling for minerals in the area since the late 1970s, without much direct influence on the constitution of social groups in Dzifasing. Groups in other Wampar villages on the southern side of the Markham River have been much more invested in the endeavour to claim ownership of the area where the drilling was occurring. In several legal battles, it was argued that WafiGolpu constitutes the ancestral homeland of all Wampar people.

When a Special Land Titles Commission was established in 2008 to determine the customary ownership of the mine site and hearings commenced in September 2009, this also had repercussions in Dzifasing. Several mpan and sagaseg started to form Incorporated Land Groups (ILG) in preparation for being recognised as 'customary landowners' as stipulated by the state law, and being able to benefit from royalties and spin-off businesses from the mining activities. Sagaseg-based group meetings began 
to be held, primarily to raise funds for the costs of registration, which entails administrative, mapping and legal service expenses. It was a time of speculations, questions, imaginations, expectations and accommodations, but also of confrontations (Bacalzo et al. 2014), as locals, led by few but influential and competing ngaeng faring, began to organise themselves in relation to ideas of opportunities and problems. A new landowner association was formed with the intent to defend the interest in the mine in the name of all Wampar. This landowner association has been involved in costly court battles with other landowner associations from neighbouring non-Wampar groups over the ownership of the mining area, and they opened the membership to anybody living in the affected communities, provided that they paid an initial membership fee.

With the prospect of the development and construction of the mine and associated mining infrastructure, lineages in Dzifasing also started to prepare to benefit from potential spin-off businesses. A mining company in PNG usually has to engage companies that are established by 'landowners' to provide necessary support services, and so people started to register business names and companies to be ready once the mine started offering contracts. There was thus a proliferation of new businesses that locals first only registered on paper, without undertaking any particular business activities.

The other two companies that started to engage landholding lineages in Dzifasing were PNG Biomass, a subsidiary of the oil and gas giant Oil Search, which is in the process of planting over 16,000 ha of eucalyptus trees to fuel two $15 \mathrm{MW}$ wood-fired power plants; and New Britain Palm Oil, a long-established oil palm company that intends to plant oil palm on at least 5,000 ha to establish a new oil mill in the area. Both companies are entering into long-term lease agreements with the landholding lineages and are actively competing against each other to secure land for their business projects. The leasing of land for eucalyptus and oil palm plantations is accomplished through ILGs, which means that the local landholding lineages must coordinate among themselves to form new ILGs on the 'clan' level. The two companies are aiding the landholding lineages in registering their ILGs and in surveying the land that the latter are willing to lease to the companies. Through the Voluntary Customary Land Registration process, a title to customary land can be issued to the ILG. Afterwards, the titled land can then be subleased to the companies. 
PNG Biomass also created a local Business Group for the participating landholding lineages that will eventually assume the day-to-day running of the plantations.

One of the prerequisites for registering an ILG is providing a list of all members of the landholding unit. The actual writing down of names of lineage members means that lineage elders now had to make a conscious decision regarding who to incorporate and, in the case of children of interethnic descent, in what terms to include them. The changing configuration of lineage membership, to either narrow or broaden the base, is not an unusual process. As Kirsch (2011, p. 93) points out, it is characteristic of kinship that kinship relations are 'always subject to telescoping and collapse for various purposes'. In this new context of corporate forms of organisation, however, the registration and listing of membership now entail legally recognised shared rights of ownership and, presumably, control of land.

The ILG law also stipulates that an ILG needs a 'management committee' of six to 10 members, with a chairperson, deputy chairperson, secretary, treasurer and at least two female representatives. The law also prescribes the collective decision-making that will have to be supported by documented proceedings. Registering a business entity with the Investment Promotion Authority (IPA ${ }^{20}$ also requires setting up a management committee and a dispute settlement authority for the Business Groups-and, for a company, the appointment of directors, a secretary and the acquiring of shareholders. All this leads to the formalisation and hierarchisation of leadership that transforms the earlier, more egalitarian, fluid and situational form of leadership.

The intricacy of registering and managing businesses and ILGs requires certain levels of skills and knowledge. For lineage groups, having members who have reached secondary or tertiary education and who have strategic work experience becomes an advantage. Young people of interethnic descent are often favourably positioned in these endeavours, as some of them have achieved an above-average education. I demonstrate this in the three case studies of young people that follow and I describe how the opportunities and limitations that they face are shaped by the

20 The IPA is the PNG government agency that is 'mandated ... [to] administers key PNG business laws' (Investment Promotion Authority 2018). 
particularities of the Wampar lineages in which they are embedded. I focus on three brother-sister sets for illustration, although each case has additional siblings.

\section{Case Studies}

Greg and Betty ${ }^{21}$ are examples of a son and daughter of a ngaeng yaner and a Wampar mother. Throughout the transition from the betel nut economy to the recent entry of large-scale capitalist projects, they fared better than most other young people of interethnic descent, as far as their experience of being included in their Wampar mother's lineage was concerned. The threat that they experienced during the height of the discursive exclusionary politics was benign and not immediate, although the overall local political climate was tense. At that time, Greg and Betty, as with their other cohorts in similar circumstances, were discursively challenging notions of who and what is 'Wampar', for they understood the rights that are attached to belonging. Greg stated:

I consider myself as a Wampar, though my father is not from Wampar ... Because I was born in a village called Dzifasing ... to a local Wampar woman who is married to someone from outside Wampar ... I speak the Wampar language fluently and I understand the cultures and traditions of the Wampar very well.

Betty similarly expressed this notion and emphasised her connection to the place: 'I have been brought up in Wampar'. ${ }^{22}$ Their father is from an island province, had a tertiary education and was professionally working in the Markham Valley when he met and then married a Wampar woman. ${ }^{23}$

In 2009, Greg was in the upper secondary school and he acknowledged that he was well integrated into his mother's lineage, as he had good relations with his maternal uncles who were the lineage leaders. Betty was in the lower secondary school and kept herself busy in school when not helping with work in the garden or marketing her produce. Their Wampar mother's lineage has an undisputed claim to a medium-sized area

21 Names in this article are pseudonyms. Since missionisation at the turn of the twentieth century, the Wampar began to use Christian or biblical names and, since then, increasingly Anglo and Anglicised names.

22 It is not unusual to hear locals speak of 'Wampar' as an ethnic identity and in reference to a place.

23 See Beer (2006b) for marriage patterns among the Wampar, including hypo- and hypergamous marriages. 
of land $\mathrm{d}^{24}$ and there was no conflict over land within their lineage. Greg was allowed by his maternal uncles to plant some cacao trees, which is unusual for a young man of his age who has a non-Wampar father. At this time, the exclusionary 'rule' limited the planting of permanent cash crops, such as cacao, only to descendants of Wampar fathers. Greg recognised that his and his siblings' situation was potentially tenuous, for, in the long run, they would be dependent on their male cousins with Wampar fathers for allowing them to continue being able to make a living and reside in Dzifasing.

Lineage leaders expressed their good impressions of Greg, his siblings and their non-Wampar father, as their comportment approximated the ideal behaviour for kin. They were ngaeng and afi gom: hardworking, focused on studying and performing the fundamental obligation of caring for the needs of their own nuclear family and their wider Wampar kin. When they were just born, their maternal uncles ensured that they would grow up in Dzifasing with them; this would be better than at their father's place of origin, which they assessed had a poorer infrastructure and fewer educational and job opportunities to offer. It was still a time of economic prosperity, with the booming betel nut economy. After the betel nut pest, however, Betty's future became tied to her choice of marriage partner due to the exclusionary 'rule' that ensued. Unlike her mother, who remained in Dzifasing after marrying a ngaeng yaner, she was made to understand that if she marries a ngaeng yaner, she would have to leave. If she wanted to remain in Dzifasing, she would have to marry a ngaeng Wampar (or remain unmarried).

In 2016, when I met Greg again, he had already earned a degree in tropical agriculture from a PNG university, but he has not yet found any secure employment. His mother's lineage has decided to lease 100 ha of their land to the oil palm company and had started to form an ILG. Their ILG comprised his mother's lineage and another lineage within the same sagaseg, and they used the name of everybody's common ancestor (Greg's great-great-great-grandfather) as the registered name for this ILG. Greg's father, mother and siblings were also listed as members of this ILG. They were among the first to receive a National ID card, one of the new preconditions to be registered on a family list in an ILG. His father,

24 The area is around $400 \mathrm{ha}$, which is neither small nor excessively large relative to other landholdings. Single-named pieces of land in the ownership of lineages can be as large as 2,000 ha, or as small as only a few hectares. 
with experience working on oil palm plantations, is an asset for palm oil production. Greg and Betty were given official titles in the management committee of their ILG. Greg, with his degree in agriculture and tertiary education, was tapped for his skills and knowledge and was made the secretary of the ILG. Betty, who had already reached secondary school, was appointed as one of the two mandatory female representatives. She and Greg are actively participating in the administrative side of the business. When I asked them how they got to this new role, they said, 'We are only helping. We let our elders decide'. They continue to acknowledge that it is their maternal uncles, the lineage leaders, who make the decisions regarding engagements with the company and the state and the disposition of responsibilities. In return, their lineage leaders acknowledge the importance of having highly skilled and better-educated members of their lineage and continue to speak highly of Greg and Betty for their comportment and contributions.

Another example of siblings, Robert and Lani also benefit from the currently inclusive trend. Their situation back in 2009 was much less favourable than that of Greg and Betty. Robert was unable to plant cacao trees on his Wampar mother's lineage land. He then thought that his future would lie elsewhere, not in Dzifasing. In contrast to Greg, Robert did not feel comfortable in Dzifasing, being aware of land disputes that his mother's lineage has with other lineages, and of the tensions between his father and his maternal uncles about helping each other out-especially in regard to sharing financial burdens, such as school fees and the costs of court battles over land. Robert's father, Francis, reached secondary school, but since he moved to Dzifasing at the height of the betel nut economy, there was no need for him to find a job. Even during that time, though, he was pushing his children to have as much schooling as possible. Robert was finishing the last year of high school in 2009 and considered making a living at his father's place of origin, where he would have ancestral rights to the land. Robert had spent a few years growing up and going to school there and had good and amicable relationships with his paternal uncles, some of whom ran small businesses. In 2009, his Wampar lineage, along with other lineages of the same sagaseg, also began preparing for an ILG registration-but they did not push through with it, as amendments to the ILG law changed the process. While Robert was listed as a member of this old ILG plan, his sister Lani was not. As she is a daughter, the rationale was that she would be marrying out anyway. 
In 2016, the situation had considerably changed for Robert and Lani. Robert had finished high school and had wanted to take tertiary level courses, but his family did not have the money to support his higher education. In the meantime, he had been helping his maternal uncles complete the registration forms to establish a building construction and maintenance company for their lineage in expectation of competing for contracts from the mining company. His maternal uncles made him one of the four directors of the company and appointed him as treasurer, as he is the only one in their small lineage with a completed higher secondary education. One of his maternal uncles said that they would not know how to run a business properly and are thus lucky to have Robert and his father as their relatives. Some of Robert's paternal uncles had experience in running businesses and had encouraged Robert's Wampar lineage to register a company in preparation for the mining to start. They also promised that they would come and assist them by imparting some of their business knowledge.

Their Wampar lineage has not yet entered into palm oil or biomass production agreements, as their land claims are all disputed. They are involved in an ongoing court battle over a piece of land on which another lineage had already started to plant eucalyptus trees for the biomass project. These unsettled land claims have thus far also prevented them from forming an ILG, as it would be too costly to pay both court costs and registration costs for an ILG without the help of the companies. Should they eventually be in a broader sagaseg-based ILG, or form one of their own, they plan to register all the family members, including Robert's father. For the time being, Robert and Lani are included as members in an ILG that their maternal grandmother's lineage is forming. Their inclusion here shows the flexibility of kin group membership that is not restricted in unilineal terms, as it can also be extended bilaterally. The lineage leaders in that group planned to engage with the oil palm company, but they later shifted to biomass. In either case, they are aware of the problematic land situation of Robert and Lani's mother's patrilineage, so they wanted to extend them the future benefits from the land lease and royalty payments.

Another case is that of Linda and Oscar. Their father is from the Sepik and he has extensive consulting experience after working at the Department of Agriculture, as well as considerable input in advising their lineage business projects. In 2016, Linda was in secondary school and, as she was performing academically well, could thus potentially reach the tertiary level of schooling. She understood through the example of her father and 
her brother that having a higher education and being highly skilled would be valuable in their ongoing lineage projects. Oscar, her older brother, had acquired computer skills and was continuing to educate himself by taking courses in business schools whenever they could afford it. Back in 2009, Linda was still in elementary school and was not yet fully aware of the ramifications of the exclusionary politics that affect children with nonWampar fathers. Oscar had already dropped out of school, after having married his high school sweetheart when he was just 18 years old. Oscar was ensuring that he stayed on good terms not only with his maternal uncles but also with his male cousins who potentially would be lineage leaders when their time comes. Through his computer skills, he helped his Wampar lineage with the paperwork for their ongoing court battles and business plans.

In 2016, I discovered that his Wampar lineage was one of the first to plant eucalyptus trees for the biomass energy project on quite a large piece of undisputed land. They had started to form an ILG on the sagaseg level, encompassing lineages in other Wampar villages long before other groups in Dzifasing and before the biomass or oil palm company became active. They received a title for their land in November 2016-the first and only ILG to do so in Dzifasing as of 2018. They also started their own business company ahead of others. Compared to the lineage groups mentioned above, many lineage leaders in this group have considerable work experience and some have college degrees. Oscar has cousins who also attained or are pursuing tertiary education. They also have much larger areas of undisputed land compared to the Wampar lineages of Greg and Robert. Cash income from the biomass plantations was, according to the lineage leaders, spent to cover the expenses of the ILG leaders in processing the surveying and titling of their land and the costs entailed while attending court cases-but there had already been a sense of disgruntlement felt by some members, including the younger generation, regarding the distribution of money. Some young people, including Oscar, voiced their apprehension regarding how the lineage leaders made decisions and complained about not being heard enough. They fear that their lineage leaders are becoming 'yes men', that they too eagerly accept the terms of the companies without negotiating for the best interest of the lineage and the future generation.

In their ILG, Oscar was listed with the second name that was taken from his maternal grandfather, not his non-Wampar father (which is the more frequent practice). Naming practices among the Wampar 
that extend to the context of interethnic marriages exhibit flexibility of affiliation, as it is a social site for balancing relationships on both sides of a married couple who keep and strengthen their respective kin ties through the naming of the children (Bacalzo 2015). Oscar being given his mother's father's name as his second name thus emphasises his link to his mother's lineage, signifying his maternal uncles' claim that he rightfully belongs to their lineage.

\section{Conclusion}

Young people of interethnic descent in Dzifasing have grown up in a rapidly changing economic environment. Most, particularly those with non-Wampar fathers, thus gained an understanding of what it is like to be excluded, and they challenged this exclusion. They have come to understand the importance of belonging to a kin group and to belong to their Wampar mother's lineage. It is here that their rights and limits to accessing land and benefits are socially taking shape-from the time when economic life revolved around the betel nut and subsistence gardens, to the end of the betel nut economy, to the corporatisation of ownership of customary land through ILGs and to the structuring of businesses that are directly linked to global capital. Local kin groups that are situated at the interface of these changing economic conditions and that are in entanglements with increasingly encompassing capitalist relations of production evaluate their social position in relation to one another and with the incoming new regime of collectivities, especially with the companies that intend to use their land. In doing so, they also define the membership of their respective lineages and make decisions about extending economic and social rights to descendants of non-Wampar fathers. Social and economic participation for these young people is thus a continuing process of negotiations - not just through time as they reach a certain age, but also as economic conditions change and power relations are recast in the reconfigured organisation of kinship and property relations.

Relations of production among the Wampar have been shifting from mostly subsistence and domestic market production-in which young people were able to directly participate-to relations that involve mechanisms far removed from their previous life world. They must apprehend these new mechanisms that are structured in the organisation and dispensation of land and the expected benefits, the access to cash 
among them. Young people, differentiated by age, gender and especially by having a ngaeng yaner father, are in a tenuous position. Previously, the primary site of struggle was access to land for subsistence and small-scale cash crop production, based on the difference in ethnicity and descent and extended to gender-which are notions that they are familiar with and that they are able to negotiate in cultural terms through the relationships in which they are embedded. With large tracts of land that are now allocated for plantations, the limits for subsistence and small-scale cash crop production are becoming more defined. With this transformation, the struggle is complicated by issues regarding the distribution of financial and other forms of expected and imagined benefits, as well as the decisions about usage and dispensation of available and remaining land.

In a much more competitive environment that is buoyed by the entry of several large-scale projects, lineage leaders come to see the value of the young people's current and potential contributions of their labour, skills and knowledge. Such views make it advantageous for young people of interethnic descent who now formally became members of their Wampar lineage, with some holding key management and administrative positions. Their negotiations for meaningful 'incorporation', however, are compounded by the new and still less familiar terms of engagement under a new form of 'corporate governance'. For what is a corporate group now, when it is still largely kinship based but also having to operate by the demands and imperatives of international business corporations? With the codification of leadership positions, legal representation and collective organisations, how conflict over power position, decisions and distribution of benefits within a lineage will unfold under this new structure of governance could yet again potentially place young people of interethnic descent in a contentious position, in this generation and in the future. Leadership not in administrative matters but in decision-making for the lineage remains the key position of power, which is primarily reserved for male descendants of a ngaeng Wampar. The turn to ILG and corporate business entities further makes the social groups' collective unit and their relationship to land governable by the state and, by extension, by the corporations that bring in values, ideas and structures of social organisation to accumulate wealth, including the concentration of the legal capacity to the ILG. ${ }^{25}$ The entrenchment of hierarchical relations

25 See the case of a PNG National Court decision in favour of the ILG against a clan in Morris $v$. Panfilo [2017] PGNC 278; N6976. It is a sample case in which an ILG gains legal recognition against an individual representing a clan. 
could potentially limit the manner and terms of negotiations, especially for those not in a position of power. One of the effects of the entry of largescale, capital-intensive projects is that there is not only a proliferation of new collective entities, but that lineage leaders are increasingly taking the immediate recourse to settle disputes in state courts, which is a costly process that syphons off the lineages' cash income and creates conflict in the way that money is distributed.

It is thus with caution that I have described here the positive side of how young people are becoming incorporated in lineage groups in this new context of corporate control and ownership of land. After all, they remain potentially vulnerable to exclusionary politics and continue to depend on the goodwill of their elders and lineage leaders. They also need to cultivate good relationships with their Wampar male cousins, who are the future lineage leaders. The possibilities and constraints for the future of young people with contentious descent are thus mediated by the fluidity of the local structures of relationships, such as the deployment of kinship practices in a culture of inclusive and reciprocal sociality, and conversely by the interpolation of a static ordering and disembedded social relationships that are increasingly taking shape with the corporatisation of economic life. It would not be in favour for young people of interethnic descent if they are regarded, once again, as competitors who only desire the money. They thus have to walk a thin line between engaging and helping and staying in the background. Such considerations underlie the disposition of the young people who experience the effects of changing economic conditions. It is understandable when Greg and Betty made it clear that they are merely helping, as usual, and not making the decisions.

\section{Acknowledgements}

I thank Bettina Beer, Willem Church, Donald Gardner, Helen Lee and Tobias Schwoerer for their helpful comments on the earlier versions and drafts of this paper. Research in PNG, in 2009 and 2010, and subsequently in 2016 and 2017, was made possible through the collaborative Wampar projects led by Bettina Beer, with the support of the Swiss National Science Foundation. I am deeply grateful to the young women and men and their families in Dzifasing for welcoming me into their homes and for helping me gain insights about their situation and ways of living. 


\section{References}

Bacalzo, D 2012, 'Transformations in kinship, land rights and social boundaries among the Wampar in Papua New Guinea and the generative agency of children of interethnic marriages', Childhood, vol. 19, no. 3, pp. 332-345, doi.org/10.1177/0907568212444740

Bacalzo, D 2015, 'Names as a means of inclusion and transformation: Naming and transcultural kinship among the Wampar, Papua New Guinea', Pacific Studies, vol. 39, nos 1-2, pp. 108-125.

Bacalzo, D, Beer, B \& Schwoerer, T 2014, 'Mining narratives, the revival of "clans" and other changes in Wampar social imaginaries: A case study from Papua New Guinea', Le Journal de la Société des Océanistes, nos 138-139, pp. 63-76, doi.org/10.4000/jso.7128

Beer, B 2006a, 'Interethnic marriages: Changing rules and shifting boundaries among the Wampar in Papua New Guinea', in B Waldis \& R Byron (eds), Migration and marriage: Heterogamy and homogamy in a changing world, LIT, Münster, pp. 20-39.

Beer, B 2006b, 'Stonhet and yelotop: Body images, physical markers and definitions of ethnic boundaries in Papua New Guinea', Anthropological Forum, vol. 16, no. 2, pp. 105-122, doi.org/10.1080/00664670600768284

Beer, B 2018, 'Gender and inequality in a postcolonial context of large-scale capitalist projects in the Markham Valley, Papua New Guinea', The Australian Journal of Anthropology, vol. 29, no. 3, pp. 348-364, doi.org/10.1111/taja. 12298

Beer, B \& Schroedter, J 2014, 'Social reproduction and ethnic boundaries: Marriage patterns through time and space among the Wampar, Papua New Guinea', Sociologus, vol. 64, no. 1, pp. 1-28, doi.org/10.3790/soc.64.1.1

Fischer, H 1975, Gabsongkeg '71: Verwandtschaft, Siedlung und Landbesitz in einem Dorf in Neuguinea, Renner, München.

Godelier, M \& Strathern, M (eds) 1991, Big men and great men: Personifications of power in Melanesia, Cambridge University Press, Cambridge.

Hann, CM 1998, 'Introduction: The embeddedness of property', in CM Hann (ed.), Property relations: Renewing the anthropological tradition, Cambridge University Press, New York, pp. 1-47. 
Investment Promotion Authority 2018, Business registration, regulation and certification, Investment Promotion Authority, viewed 19 August 2018, www.ipa.gov.pg/business-registration-regulation-and-certification/

Kirsch, S 2011, 'Science, property, and kinship in repatriation debates', Museum Anthropology, vol. 34, no. 2, pp. 91-96, doi.org/10.1111/j.15481379.2011.01110.x

Kramp, R 1999, Familienplanung in Gabensis. Fertilitätswandelausethnographischer Sicht, Reimer, Berlin.

Lancy, D 2018, Anthropological perspectives on children as helpers, workers, artisans, and laborers, Macmillan, New York, doi.org/10.1057/978-1-137-53351-7

LiPuma, E 2001, Encompassing others: The magic of modernity in Melanesia, University of Michigan Press, Ann Arbor.

Lütkes, C 1999, Gom: Arbeit und ihre Bedeutung bei den Wampar im Dorf Tararan, Papua-Neuguinea, Waxmann, Münster.

Minnegal, M, Lefort, S \& Dwyer, PD 2015, 'Reshaping the social: A comparison of Fasu and Kubo-Febi approaches to incorporating land groups', The Asia Pacific Journal of Anthropology, vol. 16, no. 5, pp. 496-513, doi.org/10.1080/ 14442213.2015.1085078

Morris v. Panfilo [2017] PGNC 278; N6976.

Noble, C, Pereira, N \& Saune, N 2011, Urban youth in the Pacific: Increasing resilience and reducing risk for involvement in crime and violence, UNDP Pacific Centre, PIFS, Suva.

Oxford Business Group 2016, The report: Papua New Guinea 2016, Oxford Business Group, viewed 19 August 2018, oxfordbusinessgroup.com/papuanew-guinea-2016

Roscoe, P 2000, 'New Guinea leadership as ethnographic analogy: A critical review', Journal of Archaeological Method and Theory, vol. 7, no. 2, pp. 79-126, doi.org/10.1023/A:1009512726844

Roscoe, P 2012, 'Before elites: The political capacities of big men', in T Kienlin \& A Zimmerman (ed.), Before elites: Alternatives to hierarchical systems in modelling social formations, Rudolph Habelt, Bonn, pp. 41-54.

Schulze, W, Fischer, H \& Lang, H 1997, Geburt und Tod: Ethnodemographische Probleme, Methoden und Ergebnisse, Reimer, Berlin.

Sharp, T, 2016, 'Trade's value: Relational transactions in the Papua New Guinea betel nut trade', Oceania, vol. 86, no. 1, pp. 75-91, doi.org/10.1002/ocea.5116 
This text is taken from Pacific Youth: Local and Global Futures, edited by Helen Lee, published 2019 by ANU Press, The Australian National University, Canberra, Australia.

doi.org/10.22459/PY.2019.03 